\title{
Morphological development of Alfagraze cultivar and Crioula alfalfa populations selected at the seedling stage
}

\author{
Daniela Favero ${ }^{1}$, Simone Meredith Scheffer-Basso ${ }^{2,}{ }^{3}$, Cerci Maria Carneiro ${ }^{2}$
}

\author{
1 Programa de Pós-graduação em Agronomia - Universidade de Passo Fundo. \\ 2 Universidade de Passo Fundo. \\ ${ }^{3}$ Bolsista CNPq.
}

\begin{abstract}
The objective of this study was to compare two populations of Crioula alfalfa cultivars, selected by the length of the seedling second internode (Crioula-LI, long internode $=2.5 \mathrm{~cm}$; Crioula-SI, short internode $=1.5 \mathrm{~cm}$ ) with Alfagraze cultivar in order to verify the seedling morphology value for the selection of more prostrate plants. The plants were grown individually in pots in a semi-protected environment and harvested at 74, 104, 134, 164, 194 and 224 days. Crioula populations varied in terms of height, leaf area, root volume, dry matter yield, and the Crioula-LI population outnumbered that of Crioula-SI. For height, length of internode and primary stem, Alfagraze $(45.1 \mathrm{~cm}, 2.1 \mathrm{~cm}$ and $16.7 \mathrm{~cm}$ ) was similar to Crioula-SI $(37.6 \mathrm{~cm}, 2.3 \mathrm{~cm}$ and $18.2 \mathrm{~cm})$; however, the leaf area $\left(2.028 \mathrm{~cm}^{2}\right)$ and dry matter yield (20.3 g) did not differ from those of Crioula-LI $\left(2.021 \mathrm{~cm}^{2}, 21 \mathrm{~g}\right.$ ). The Alfagraze cultivar surpassed the Crioula population in terms of procumbency, crown diameter and crown stem number. At the flowering stage, the Crioula-LI cultivar had total stem number (61/plant) higher than Alfagraze (47/plant) and Crioula-SI (41/plant) cultivars. The length of the seedling internode is a promising marker for the selection of alfalfa, being a predictive factor for plant height, stem number, root volume and leaf area, and can be useful in the alfalfa breeding.
\end{abstract}

Key Words: breeding, grazing-type, hay-type, internode

\section{Desenvolvimento morfológico do cultivar Alfagraze e de populações de alfafa Crioula selecionadas em estádio de plântula}

\begin{abstract}
RESUMO - O objetivo neste trabalho foi comparar duas populações de alfafa cv. Crioula, selecionadas pelo comprimento do segundo entrenó da plântula (Crioula-EL, entrenó longo $=2,5 \mathrm{~cm}$; Crioula-EC, entrenó curto $=1,5 \mathrm{~cm}$ ), e o cultivar Alfagraze, com a finalidade de verificar o valor da morfologia da plântula para seleção de plantas mais prostradas. As plantas foram cultivadas individualmente em vasos, em ambiente semiprotegido, e colhidas aos 74, 104, 134, 164, 194 e 224 dias de idade. As populações de Crioula variaram entre si quanto à altura, à área foliar, ao volume de raízes e à produção de matéria seca, que foram maiores na Crioula-EL. A altura e o comprimento de entrenó e de haste primária foram similares entre as populações Alfagraze $(45,1 \mathrm{~cm} ; 2,1 \mathrm{~cm} ; 16,7 \mathrm{~cm})$ e Crioula-EC $(37,6 \mathrm{~cm} ; 2,3 \mathrm{~cm} ; 18,2 \mathrm{~cm})$. A área foliar $\left(2.028 \mathrm{~cm}^{2}\right)$ e a produção de matéria seca (20,3 g) da população Alfagraze não diferiram da Crioula-EL $\left(2.021 \mathrm{~cm}^{2} ; 21 \mathrm{~g}\right)$. O cultivar Alfagraze superou as populações Crioula quanto às características decumbência, diâmetro da coroa e proporção de hastes da coroa. No estádio de florescimento, o cultivar Crioula-EL apresentou maior número de hastes totais (61/planta) em relação ao Alfagraze (47/planta) e Crioula-EC (41/planta). O comprimento do entrenó de plântula é um marcador morfológico promissor na seleção de populações de alfafa; é preditivo para altura de planta, número de hastes, volume de raízes e área foliar e pode auxiliar nos trabalhos de melhoramento.
\end{abstract}

Palavras-chave: entrenó, melhoramento, tipo feno, tipo pastejo

\section{Introduction}

Crioula is the most widely grown alfalfa cultivar in Brazil. It originates from a joint selection process, made both by man and nature, encompassing a population adapted to current crop conditions in the state of Rio Grande do Sul, which has outperformed other cultivars (Oliveira et al.,
1993). Even though Crioula is a hay-type cultivar, some studies demonstrate variability in its germplasm, making it suitable for grazing (Perez, 2003).

The development of grazing-type alfalfa was initially targeted at the identification of a trait which, once improved in the germplasm, could guarantee grazing persistence (Bouton, 1996), that is, selecting morphological traits that 
could enhance the grazing tolerance. In this phase, the existence of bud-forming roots was the major trait, but that could not be confirmed. Other traits included: crowns, underground bud growth, broad crowns, profuse and asynchronous bud formation, maintenance of the nonstructural carbohydrates (NSC) level and pest resistance. Furthermore, the growth habit plays an important role, and according to Brummer \& Bouton (1991), procumbent plants show better persistence than erect plants when submitted to continuous grazing.

The growth habit is characterized by branch orientation, consistency, branching degree, among other factors. According to Perez (2003), adaptation to grazing may also be correlated with internode length. In his work, this author noted variability in the Crioula cultivar in terms of this trait at the seedling stage, which may allow the early selection of plants adapted to grazing, based on the height of the first node, regarded as the point of insertion of the unifoliolate leaf. The use of the growth habit of seedlings as a criterion for the selection of growth habit in alfalfa is unknown. However, Fowler et al. (1999) associated radicle length of this species with resistance to seedling damping-off caused by Rhizoctonia solani Kuhn. In Cotula sp., Lloyd (1981) noted that the primary plant axis did not elongate and gradually assumed a horizontal position in procumbent species, as opposed to erect species.

The aim of the present study was to assess the morphological development of two populations of Crioula alfalfa cultivars, selected at the seedling stage, compared to the Alfagraze cultivar, in order to analyze seedling morphology for the selection of more grazing-tolerant plants. Among other objectives, our goal was to determine whether alfalfa populations differ in terms of growth habit; at which age differences occur; what the major characteristics of grazing-type and hay-type alfalfa are; and whether the seedling internode length can be used in the selection of alfalfa cultivars.

\section{Material and Methods}

The study was carried out between May and December 2004, in Passo Fundo ( $28^{\circ} 15^{\prime} \mathrm{S}$ and $52^{\circ} 24^{\prime} \mathrm{W}$ and altitude of $687 \mathrm{~m}$ ), state of Rio Grande do Sul, Brazil. This region has a humid subtropical climate (Cfa), with an average annual temperature of $22^{\circ} \mathrm{C}$ (Moreno, 1961) (Figure 1). Three alfalfa populations were assessed (two Crioula cultivar populations, selected at the seedling stage, and one Alfagraze cultivar control population), at six ages, using a bifactor $3 \times 6$ model. The plants were fully harvested at 74, 104, 134, 164, 194 and

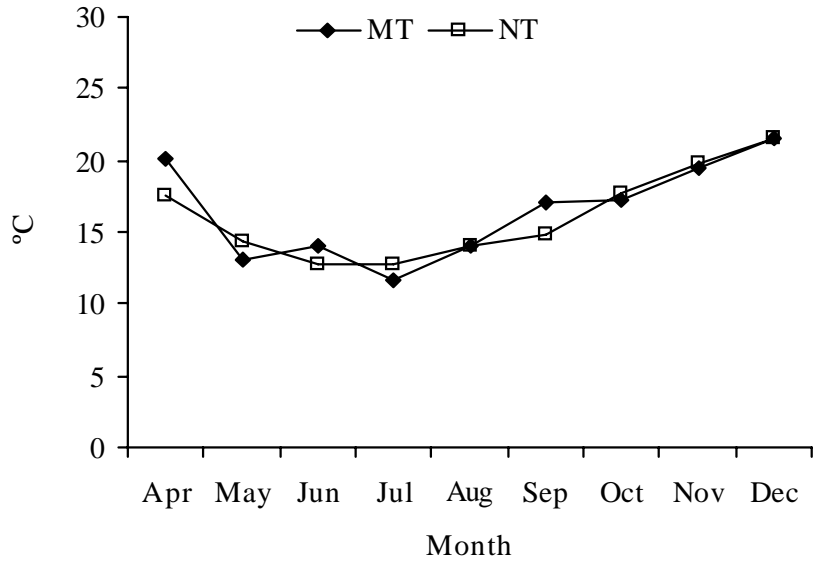

Figure 1 - Average monthly temperatures (MT) and normal regional temperatures (NT $=30$-year average) during the experimental period. Passo Fundo, state of Rio Grande do Sul, Brazil. Source: www.cnpt.embrapa.br.

224 days. Experimental units consisted of pots, and a causal block design with six replications was used. The pots were transferred from one place to another within each block on a weekly basis so as to minimize experimental error.

The selection of populations was conducted on April 26, 2004 by sowing the cultivars in cell trays containing a commercially available substrate. Five trays were used for the Crioula cultivars (620 cells) and one tray for the Alfagraze cultivar (124 cells). On the $44^{\text {th }}$ day after the emergence of seedlings, before contractile growth, the populations were selected using the length of the second internode (stem segment between the cotyledons and the first unifoliolate leaf) as morphological marker. Approximately 50 seedlings with long internode $(2.5 \mathrm{~cm})$, referred to as Crioula-LI, and with short internode $(1.5 \mathrm{~cm})$ were obtained, similarly to those of the Alfagraze cultivar. The primary stem was tagged with a colored string to allow for growth assessment.

The definitive experimental units consisted of plastic cups and pots, depending on the age of plants to be harvested: 500-mL plastic cups for 74 and 104 days; $1,000-m L$ pots for 124 and 164 days; and 5,000-mL pots for the remaining ages. Some gravel was placed at the bottom of the cups or pots to help with drainage. The substrate consisted of a mixture of soil from a crop field, deep swine bedding, and sand at the respective ratio of 60:30:10. After the substrate was placed in the cups or pots, it was disinfected with aqueous solution of $5 \%$ formaldehyde, and irrigated until runoff occurred. The cups or pots were covered with black plastic mulch for 24 hours and two weeks later, the seedlings were transplanted (one seedling 
per experimental unit). The physicochemical analysis of the substrate yielded the following results: $\mathrm{pH}=5.3 \%$; $\mathrm{P}=51 \mathrm{mg} / \mathrm{L} ; \mathrm{K}=201 \mathrm{mg} / \mathrm{L}$; clay = 36\%; organic matter = $6.1 \% ; \mathrm{Al}=0.0 \mathrm{cmol}_{\mathrm{C}} / \mathrm{dm} ; \mathrm{Ca}=6.7 \mathrm{cmol}_{\mathrm{C}} / \mathrm{dm} ; \mathrm{Mg}=$ $6.4 \mathrm{cmol}_{\mathrm{c}} / \mathrm{dm} ; \mathrm{H}+\mathrm{AL}=3.9 \mathrm{cmol}_{\mathrm{c}} / \mathrm{dm}$; and $\mathrm{CEC}=$ $17.5 \mathrm{cmol}_{\mathrm{C}} / \mathrm{dm}$. Due to the lack of aluminum and to the adequate nutrient concentration in the substrate, the use of lime and fertilizers was not necessary. Inoculation with Rhizobium meliloti was performed when the plants were 60 days old by applying $250 \mathrm{~mL}$ of commercially available inoculant per pot at $2 \mathrm{~g} / \mathrm{L}$. During the experimental period, abamectin 18CE at $0.01 \%$ was applied twice. The plants were grown in a greenhouse with clear colorless polyethylene mulch, with walls made of Clarite ${ }^{\circledR}$ plastic film. The plants had no water restriction and were submitted to automatic sprinkling irrigation.

The plants were assessed using linear measurements, as well as counting, surface, weight and volume measurements (Benincasa, 2003). Height (H) and diameter (D) of the aerial part were measured immediately before the removal of the plants from the pots. The $\mathrm{D}: \mathrm{H}$ ratio was used as the procumbency degree, with higher values indicating more pronounced creeping-rootedness. The plants were later rinsed under running water and taken to the laboratory, where the underground part was separated into roots and crown, and the aerial part was divided into stems and leaves. The crown was regarded as the thick segment adjacent to the cotyledonary node (Márquez-Ortiz et al.,
1996). Other measurements included: length of the primary stem, internode length of the longest stem, crown diameter, length of the largest root, number of crown stems (CS), axillary stems (AS) and total stems (CS + AS), root volume and dry matter (DM) contents of leaves, stems and roots. After the separation of green leaves, the leaf area of each plant was estimated using a Licor 3100A electronic planimeter. The dry matter content of aerial parts was obtained by drying them in an oven with forced air at $60^{\circ} \mathrm{C}$ until a constant weight was achieved. Phenological events were followed up and the plants were classified into vegetative stage or flowering stage.

Data was initially submitted to analysis of variance using a 3 (population) $\times 6$ (age) bifactor model. Results have shown some difference between the populations at ages compatible with the various phenological stages; therefore a new 3 (population) $\times 2$ (phenological stage $=$ vegetative growth and flowering) analysis was made using a bifactor model, with comparison of means by Tukey test with significance level of 5\%.

\section{Results and Discussion}

With regard to the mean of phenological stages, there were variations in the traits related to the expansion and accumulation of the dry matter present in the aerial part and the root components, without interaction with population (Table 1). At the flowering stage, plants showed lower

Table 1 - Morphophysiological characteristics of alfalfa populations selected at the seedling stage (Crioula-LI = long internode; Crioula-SI = short internode) compared to the Alfagraze cultivar

\begin{tabular}{|c|c|c|c|c|c|}
\hline \multirow[t]{3}{*}{ Trait } & \multicolumn{3}{|c|}{ Population } & \multicolumn{2}{|c|}{ Phenological stage } \\
\hline & \multirow[t]{2}{*}{ Alfagraze } & \multicolumn{2}{|c|}{ Crioula } & \multirow[t]{2}{*}{ Vegetative } & \multirow[t]{2}{*}{ Flowering } \\
\hline & & Short internode (SI) & Long internode (LI) & & \\
\hline Height (cm) & $45.1 \mathrm{~B}$ & $37.6 \mathrm{~B}$ & $54.3 \mathrm{~A}$ & $25.4 \mathrm{~B}$ & $66.0 \mathrm{~A}$ \\
\hline Primary stem (cm) & 16.7B & $18.2 \mathrm{~B}$ & $24.0 \mathrm{~A}$ & $20.6 \mathrm{~A}$ & $18.6 \mathrm{~A}$ \\
\hline Internode (cm) & $2.1 \mathrm{~B}$ & $2.3 \mathrm{AB}$ & $2.9 \mathrm{~A}$ & $2.0 \mathrm{~B}$ & $2.9 \mathrm{~A}$ \\
\hline Nodes (n./stem) & 9.3A & $9.6 \mathrm{~A}$ & $8.6 \mathrm{~A}$ & $10.0 \mathrm{~A}$ & $8.4 \mathrm{~B}$ \\
\hline Leaf area (cm²/plant) & $2.028 \mathrm{~A}$ & $1.455 B$ & $2.021 \mathrm{~A}$ & $760 \mathrm{~B}$ & $2.910 \mathrm{~A}$ \\
\hline Root volume ( $\mathrm{cm}^{3} /$ plant $)$ & 43.3АВ & 34.9B & $51.2 \mathrm{~A}$ & 16.3B & $70.0 \mathrm{~A}$ \\
\hline Procumbency (diameter:height ratio) & $1.2 \mathrm{~A}$ & $0.9 \mathrm{~B}$ & $0.8 \mathrm{~B}$ & $1.0 \mathrm{~A}$ & $0.9 \mathrm{~B}$ \\
\hline Crown diameter (mm) & $18.1 \mathrm{~A}$ & $12.4 \mathrm{~B}$ & $13.5 \mathrm{~B}$ & $7.1 \mathrm{~B}$ & $22.3 \mathrm{~A}$ \\
\hline Crown stems (n./plant) & $8.0 \mathrm{~A}$ & $5.1 \mathrm{~B}$ & $4.0 \mathrm{~B}$ & $3.9 \mathrm{~B}$ & $8.0 \mathrm{~A}$ \\
\hline \multirow[t]{2}{*}{ Crown stems (\%) } & $37.7 \mathrm{~A}$ & $32.1 \mathrm{~B}$ & $27.8 \mathrm{~B}$ & 45.7A & $19.4 \mathrm{~B}$ \\
\hline & \multicolumn{5}{|c|}{ Dry matter yield (g DM/plant) } \\
\hline Leaf & 8.9A & $6.2 \mathrm{~B}$ & $8.8 \mathrm{~A}$ & $2.9 \mathrm{~B}$ & $13.0 \mathrm{~A}$ \\
\hline Stem & $11.5 \mathrm{AB}$ & $8.3 \mathrm{~B}$ & $12.2 \mathrm{~A}$ & $2.5 \mathrm{~B}$ & $18.7 \mathrm{~A}$ \\
\hline Leaf:stem ratio & $1.42 \mathrm{~A}$ & $1.0 \mathrm{~A}$ & $1.0 \mathrm{~A}$ & $1.58 \mathrm{~A}$ & $0.7 \mathrm{~B}$ \\
\hline Aerial part & $20.3 \mathrm{~A}$ & $14.5 B$ & $21.0 \mathrm{~A}$ & $5.4 \mathrm{~B}$ & $31.8 \mathrm{~A}$ \\
\hline Roots & $26.7 \mathrm{~A}$ & $17.4 \mathrm{~B}$ & $22.0 \mathrm{AB}$ & $4.4 \mathrm{~B}$ & $39.6 \mathrm{~A}$ \\
\hline Total & $47.1 \mathrm{~A}$ & $31.9 B$ & $43.0 \mathrm{~A}$ & $9.9 \mathrm{~B}$ & $71.4 \mathrm{~A}$ \\
\hline Roots:aerial part ratio & $1.2 \mathrm{~A}$ & $0.9 \mathrm{~A}$ & $1.0 \mathrm{~A}$ & $0.9 \mathrm{~B}$ & $1.2 \mathrm{~A}$ \\
\hline
\end{tabular}

Means followed by the same lower case letter in the column and by upper case within a row do not differ according to Tukey test at a $5 \%$ significance level. 
procumbency due to internode elongation and to the smaller internode number, as commonly observed at this phenological stage. This result implied the reduction of the leaf-stem ratio. The dry matter allocation was equally changed in the root-aerial part ratio, since the formation of the underground system was prioritized, and so was the root volume. At the reproductive stage, the cultivars showed a larger number of crown stems, but their contribution to the total stem number was lower, thus corroborating that the axillary branching is more intense in alfalfa.

Variability among cultivars occurred mainly for the Alfagraze cultivar traits when compared to Crioula cultivar populations, but in different traits. In terms of morphological traits such as height, internode and primary stem, the Alfagraze cultivar was similar to Crioula-SI cultivar, suggesting a correlation with the selection criterion established for the populations (length of the seedling's second internode). This cultivar, which was more procumbent and did not differ from the Crioula-LI cultivar in relation to leaf area and DM yield (Table 1). Leguminous plants with more procumbent stems are usually less productive than those with erect stems, but they can be submitted to continuous grazing or clipping because their apical and axillary buds are better protected and often have a larger leaf area close to the soil surface (Nelson \& Moser, 1994). Nevertheless, the Alfagraze cultivar did not meet these expectations, since its production was similar to those of hay-type cultivars (Bouton et al., 1991).

Despite the fact that the primary stem, in which the selection was carried out, did not elongate during plant growth, the differences persisted between populations, and therefore, Crioula-LI was 32\% better than Crioula-SI cultivar. The interrupted growth of this stem, due to the inactivation of the shoot meristem, determined its transient contribution towards the leaf area formation in alfalfa.

Besides the height and length of the primary stem, the Crioula cultivars populations differed between themselves in terms of root volume and of DM yield for other components, confirming that the seedling morphology can have a predictive value for these traits and therefore help with the initial selection steps. Nonetheless, a type similar to that of the Alfagraze cultivar, with procumbency, combined with larger DM yield and remarkable formation of crown stems, was not observed. The Crioula-SI cultivar population, which resembled that of the Alfagraze cultivar at the seedling stage, was basically smaller and less productive. On the other hand, in the study undertaken by Favero et al. (2008), this same population, when submitted to intense $(2 \mathrm{~cm})$ and frequent (weekly) clippings, revealed a $50 \%$ persistence rate, whereas the Crioula-LI cultivar did not survive. In the same study, the Alfagraze cultivar survived remarkably well, exhibiting the highest tolerance for this clipping management. Also, the Alfagraze cultivar revealed important persistence traits such as procumbency, larger number of crown stems, crown diameter and percentage of crown stems in relation to the total stem number.

Usually, height is related to the plant's growth habit the tallest plants are regarded as erect - and, in forage legumes, height is considered for the selection of pasture plants. Campbell et al. (1997), in a study on Medicago ruthenica L., described variations ranging from erect to procumbent growth habits and suggested that erect plants could be selected for hay production, whereas procumbent plants are more adapted to grazing. Pecetti et al. (1995) observed a stark difference between the morphological types of alfalfa, which were classified into seven growth habit groups (ranging from procumbent to totally erect), which has implications for the selection of pasture plants. The Alfagraze cultivar is described as semi-erect (Bouton et al., 1991), which was confirmed in this study by procumbency (Table 1) and by the plagiotropic orientation of the crown stems (Figure 2).

Márquez-Ortiz et al. (1999) emphasized the importance of the crown and stems of this region for obtaining more grazing-tolerant alfalfa cultivars. According to Leach (1969), regrowth from buds close to the crown is especially important in the period that immediately follows defoliation, when reduction of the leaf area is the major limiting growth factor.

The Alfagraze cultivar showed a cyclical behavior in terms of crown stem formation (Figure 3). At the beginning of the flowering stage, at the age of 164 days, there was a reduction in stem formation, when it was similar to that of

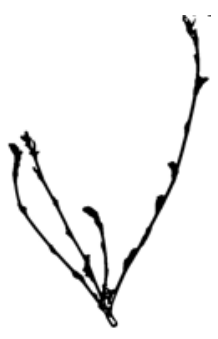

Crioula-LI

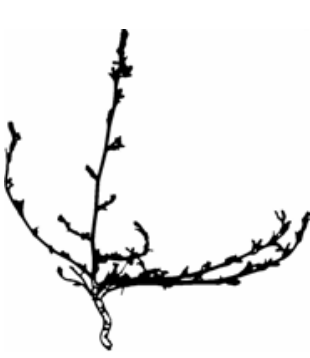

Alfagraze

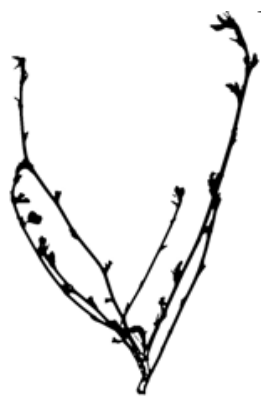

Crioula-SI
Figure 2 - Aspect regarding the growth orientation of crown stems of alfalfa populations selected at the seedling stage (Crioula-LI = long internode; Crioula-SI = short internode; and Alfagraze) at the age of 104 days. 

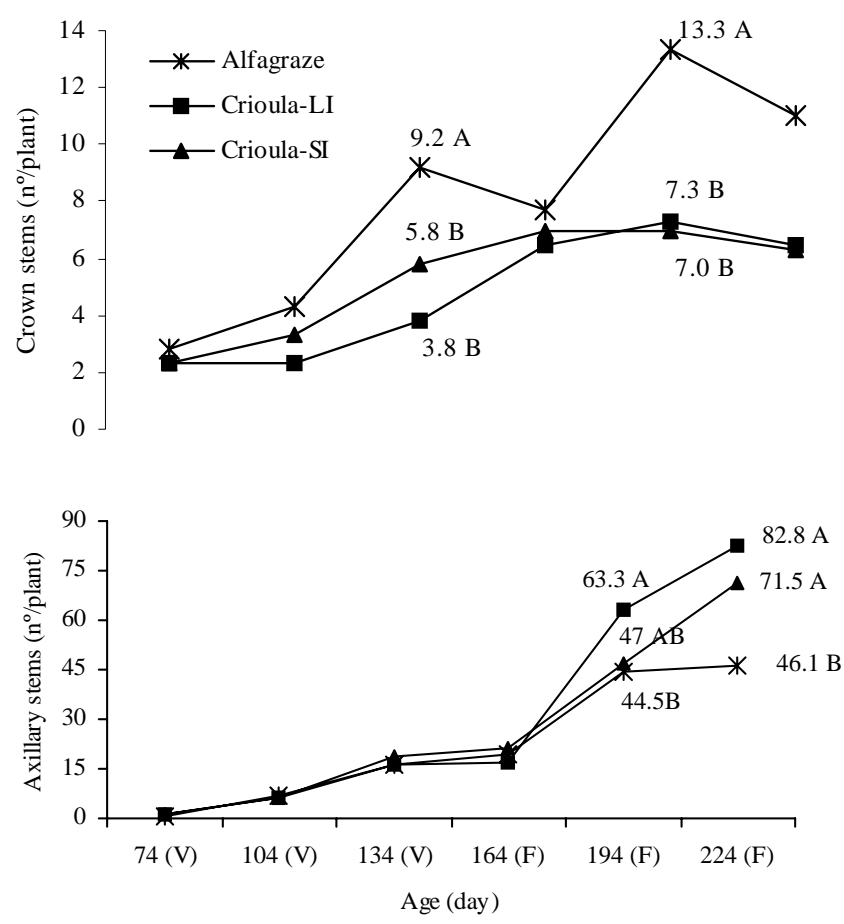

Figure 3 - Stem number of alfalfa populations selected at the seedling stage (Crioula-LI = long internode; Crioula-SI = short internode; and Alfagraze) at different ages and phenological stages ( $\mathrm{V}$ = vegetative; $\mathrm{F}$ = flowering). Different letters indicate significant difference between populations $(\mathrm{P}<0.01)$ according to Tukey test.

Crioula populations. However, 30 days after the beginning of the flowering stage, at the age of 194 days, this cultivar had nearly twice the crown stem number as other populations, which indicates reactivation of the process, but this is followed by a new decline and by stabilization in the formation of axillary stems. This asynchronous stem formation is a desirable trait in plants that are more adapted to grazing (Leach, 1978).

On the other hand, the higher relative amount of axillary stems, located along the branches, and the erect growth of Crioula populations demonstrate that they are more adapted to hay production, and that they rely more on the preservation of axillary buds for regrowth. Leach (1970) showed that $90 \%$ of the DM production in alfalfa arises from the shoots jutting out from the crown or from sites up to $2 \mathrm{~cm}$ above it. This is an important aspect of the analyzed populations, since the higher relative amount of crown stems of the Alfagraze cultivar indicates a plant more adapted to grazing.

The dynamics of total stem formation was more evident in adult plants, mainly in Crioula cultivar populations (Table 2) due to the increase in the number of axillary stems (Figure 3). Crioula-LI populations, which stood
Table 2 - Stem number of alfalfa populations selected at the seedling stage

\begin{tabular}{|c|c|c|}
\hline \multirow[t]{2}{*}{ Population } & \multicolumn{2}{|c|}{ Phenological stage } \\
\hline & Vegetative & Flowering \\
\hline & \multicolumn{2}{|c|}{ n./plant } \\
\hline Alfagraze & $13.6 \mathrm{aB}$ & $47.4 \mathrm{bA}$ \\
\hline Crioula - short internode & 9.3aB & $41.0 \mathrm{bA}$ \\
\hline Crioula - long internode & $10.8 \mathrm{aB}$ & $61.0 \mathrm{aA}$ \\
\hline
\end{tabular}

Means followed by the same lower case letter in the column and by upper case letter within a row do not differ according to Tukey test at 5\% significance level.

out in this study for their larger stem number at the flowering stage and for their greater average height, also showed the same behavior under clipping management. Favero et al. (2008) mentioned that this population benefited more from less frequent clippings, every 30 days, outperforming Crioula-SI and Alfagraze cultivars in terms of dry matter yield.

\section{Conclusions}

The internode length of a seedling is a thriving morphological marker for the selection of alfalfa cultivars and a predictive factor for morphophysiological traits, especially height. The short-internode alfalfa population is similar to the grazing-type (Alfagraze) cultivar in terms of plant height, but it does not have the same procumbency, dry matter yield, crown diameter and crown stem number. The long-internode alfalfa population has a greater height, leaf area, root volume and dry matter yield than the short-internode alfalfa population. The grazing-type Alfagraze cultivar outperforms the hay-type Crioula cultivar in terms of crown stem number, crown diameter and procumbency, which are important traits for the selection of more grazing-tolerant alfalfa cultivars. The total stem number of alfalfa cultivars with different growth habits is more distinct at the flowering stage.

\section{Literature Cited}

BENINCASA, M.P. Análise de crescimento de plantas (noções básicas). Jaboticabal: FUNEP, 2003. 41p.

BOUTON, J.H.; SMITH, S.R.; WOOD, D.T. et al. Registration of 'Alfagraze' alfalfa. Crop Science, v.31, p.479, 1991.

BOUTON, J.H. [1996]. New uses for alfalfa and other "old" forage legumes. In: JANICK, J. (Ed.). Progress in new crops. Alexandria: ASHS Press, 1996. Disponível em: <htpp://www.hort.purdue.edu/ newcrop/pproceedings1996;V3-V251.html> Acesso em: 06/17/2007.

BRUMMER, E.C.; BOUTON, J.H. Plant traits associated with grazing-tolerant alfalfa. Agronomy Journal, v.83, p.9961000, 1991. 
CAMPBELL, T.A.; BAO, G.; XIA, Z.L. Agronomic evaluation of Medicago ruthenica collected in Inner Mongolia. Crop Science, v.37, p.599-604, 1997.

FAVERO, D.; SCHEFFER-BASSO, S.M.; DALL'AGNOL, M. et al. Desempenho de populações de alfafa sob desfolhação. Revista Brasileira de Zootecnia, v.37, p.589-595, 2008.

FOWLER, M.C.; MILLER-GARVIN, J.E.; REGULINSKI, D.P. et al. Association of alfalfa radicle length with resistance to Rhizoctonia damping-off. Crop Science, v.39, p.659-661, 1999.

LEACH, G.J. Shoot numbers, shoot size, and yield of regrowth in three Lucerne cultivars. Australian Journal of Agricultural Research, v.20, p.425-434, 1969.

LEACH, G.J. Shoot growth on lucerne plants cut at different heights. Australian Journal of Agricultural Research, v.21, p.583-591, 1970.

LEACH, G.J. The ecology of lucerne pasture. In: WILSON, J.R. (Ed.). Plant relations in pastures. Melbourne: CSIRO, 1978. p.290-308.

LLOYD, D.G. Evolution of prostrate and erect habits in Cotula section Leptinella and other New Zealand plant groups. New Zealand Journal of Botany, v.19, p.24-253, 1981.

MARQUEZ-ORTIZ, J.J.; JOHNSON, L.D.; BARNES, D.K. et al. Crown morphology relationships among alfalfa plant introductions and cultivars. Crop Science, v.36, p.766-767, 1996.
MARQUEZ-ORTIZ, J.J.; LAMB, J.F.S.; JOHNSON, L.D. et al. Heritability of crown traits in alfalfa. Crop Science, v.39, p.38-43, 1999.

MOREnO, J.A. Clima do Rio Grande do Sul. Porto Alegre: Secretaria de Agricultura, 1961. 41p.

NELSON, C.J.; MOSER, L.E. Plant factors affecting forage quality. In: FAHLEY JR., G.G.; COLLINS, M.; MERTENS, D.R. (Eds.) Forage quality, evaluation and utilization. Madison: Library of Congress, 1994. p.115-154.

OLIVEIRA, P.R.D.; PAIM, N.R.; CZERMAINSKI, A.B.C. Seleção para rendimento e qualidade da forragem em alfafa crioula Pesquisa Agropecuária Brasileira, v.29, n.9, p.1039-1044 1993.

PECETTI, L.; VALENTINI, P.; PIANO, E. Development of grazing-type lucerne: yield variation and relationship with plant morphology in the Medicago sativa complex. In: MEETING OF THE MEDITERRANEAN WORKING GROUP OF THE FAO/CIHEAM INTER-REGIONAL RESEARCH AND DEVELOPMENT NETWORK ON PASTURES AND FODDER CROPS, 29., 1995, Avignon. Proceedings... Rome: FAO, 1995. p.45-48.

PEREZ, N.B. Melhoramento genético de leguminosas de clima temperado - alfafa (Medicago sativa L.) e cornichão (Lotus corniculatus L.) para aptidão ao pastejo. 2003. 175f. Tese (Doutorado em Zootecnia) - Universidade Federal do Rio Grande do Sul, Porto Alegre, 2003. 